\title{
Genitourinary Fistula
}

National Cancer Institute

\section{Source}

National Cancer Institute. Genitourinary Fistula. NCI Thesaurus. Code C9489.

An abnormal tract between the urinary system and the anterior surface of the

gynecologic structures. These include vesico-vaginal, urethro-vaginal, uretero-vaginal,

vesico-uterine, uretero-uterine, vesico-cervical, vesico-utero-vaginal fistulae. 